\title{
FACTORS AFFECTING ENTREPRENEURIAL ATTITUDE OF FEMALE UNIVERSITY STUDENTS IN PAKISTAN \\ Shahnaz Perveen ${ }^{1 *}$, Muhammad Ayub Buzdar ${ }^{2},{\text { Akhtar } \text { Ali }^{3}}^{3}$ \\ ${ }^{1 *}$ Assistant Professor, Department of Education, The Government Sadiq College Women University, Bahawalpur, Pakistan; ${ }^{2}$ Assistant Professor, Department of Education, Government College University Faisalabad, Pakistan; \\ ${ }^{3}$ Professor, Department of Education, The Islamia University of Bahawalpur, Pakistan. \\ Email: ${ }^{1 *}$ drshahnaz@gscwu.edu.pk, ${ }^{2}$ ayubbuzdar@gmail.com, ${ }^{3}$ akhtariub@ hotmail.co.uk
}

Article History: Received on $2^{\text {nd }}$ March 2021, Revised on $8^{\text {th }}$ April 2021, Published on $18^{\text {th }}$ April 2021

\section{Abstract}

Purpose of the study: This research study aims to measure the entrepreneurial attitude of female university students and investigates the factors contributing to the development of entrepreneurial attitude among female students in Pakistan. The core objective of the study was to develop entrepreneurial attitudes among females and make them capable to adopt small-scale businesses.

Methodology: A quantitative approach was employed to measure the entrepreneurial attitude of female students and further exploring different factors affecting the attitude of female students towards adopting the business as a career option. In this study, a survey method was used in which quantitative data on female students' entrepreneurial attitude and different affecting factors were collected from 2576 female students from eight public sector universities located in Punjab province. The entrepreneurial attitude scale was used as a survey instrument originally developed by Ali, Topping, and Tariq (2011) and further modified by the researchers to measure the entrepreneurial attitude of female students. A factor-based scale was developed to measure the effect of these factors on female students' entrepreneurial attitudes. The collected data were analyzed using descriptive statistics, Pearson correlation, and regression techniques by using SPSS 16th Version.

Results: Findings of multiple regression analysis exhibits that the role of education is the best contributor to the female students' entrepreneurial attitude. The other contributing factors are family support, technological assistance, business environment, and social support but their contribution is small whereas government initiatives and legal provisions were not supportive for developing entrepreneurial attitudes among female students.

Applications of this study: This study can be useful for arranging entrepreneurial career development programs for the development of the entrepreneurial attitude among female students and make them capable to start their entrepreneurial endeavours.

Novelty/Originality of this study: The novelty of this study was to investigate the effects of different familial, social, educational, political, environmental, and legal factors on female students' entrepreneurial attitudes.

Keywords: Entrepreneurial Education, Female University Students, Entrepreneurial Attitude, Family Support, Government Initiatives, Business Environment.

\section{INTRODUCTION}

Entrepreneurship is imperative in the socio-economic growth of all nations. It performs as a facilitator for generating job opportunities and increasing the Gross Domestic Product (GDP) of the nations (Gürol \& Atsan, 2006). Approximately, $80 \%$ of the worldwide GDP originates from small and medium-sized enterprises and many work opportunities (Tripathi, 2019). It is a route through which individuals pursue different prospects without concerning the resources they presently govern (Asian Productivity Organization, 2003). Education is an important mean of knowledge and advancement in terms of developing innovative businesses and their existence and especially entrepreneurship education which can produce the flow of potential entrepreneurs from the education system by nurturing entrepreneurial attributes (Ndofirepi, 2020). Entrepreneurship education is a primary source of developing the entrepreneurial attitude of both prospective and emerging entrepreneurs (Potter \& Marchese, 2008). It is effective and useful for business as well as science and engineering students (Maresch et al., 2016).

In 2020, Global Entrepreneurship Monitor identified that in "Total Early-Stage Entrepreneurial Activity (TEA)", Latin America and Caribbean regions had the highest levels of Total early-stage Entrepreneurial Activity. Even the first six highest levels of "Total early-stage Entrepreneurial Activity" were from the Latin America and Caribbean regions. Among the 50 sampled countries, Chile and Ecuador were the top countries starting and running a new business. In contrast, Pakistan remained the lowest with less than $4 \%$ of adults starting and running a new business. The survey showed that in mainstream economies, motivating people to launch a business is significant and the most common policy objective. But maintaining these startups into long-standing economically defensible businesses is also imperative for the economies. Turning a startup into maturity is not an easy task and even not everyone handles it. The ones need to strive hard to contribute to the economy through creating employment and revenues and turning out different services and goods for the public to purchase (Bosma et al., 2020). The governments can play a substantial part to provide support to entrepreneurs to start and maintain their businesses. But unfortunately, in Pakistan institutional and 
shareholder assistance and overall governance infrastructure present a deprived situation. If the government is critical to growing entrepreneurship and skill development in its individuals, it must promote institutional and shareholders support system (Shabbir et al., 2018).

Entrepreneurial activities are very limited in Pakistan when compare with other South Asian countries such as India, Sri Lanka, and Bangladesh or even compare to other Asian countries (Xavier et al., 2012; World Bank, 2007). In 2012, GEM reported that Pakistan remained the lowest in nascent entrepreneurial activity (Xavier et al., 2012). Asian Development Bank (2014) highlighted significant complexities and difficulties in doing entrepreneurship in Pakistan and referred to corruption among the top critical causes. In contrast, many states of Europe appear as the easiest places to start a business such as United Kingdom, Poland, Sweden, Netherlands, and Norway. Even Indian small and mediumsized enterprises are not as much susceptible to economic and environmental uncertainties as in Pakistan. The business community in Pakistan largely depends on the government's policy-making, planning, and incentives for their businesses. Despite showing eagerness to start their businesses, they generally have more concerns in tax reliefs, subsidizations, and repayments (Mian \& Qureshi, 2011). Still, a high proportion of Pakistani youth perceived ample prospects to launch a business in the country (Bosma et al., 2020).

Pakistan is a developing country and it generally has given less attention to entrepreneurship and especially the small and medium-sized enterprises (SME). Pakistan's usual annual business entrance ratio is lower than regional averages around the world (Klapper \& Delgado, 2007). Moreover, a huge amount of new firms stays unregistered in small scale informal industrial segment in Pakistan. According to the Economic Census of Pakistan 2005, SMEs establish more than 90 percent of the total 3.2 million private businesses with the engagement of approximately 78 percent of the nonagricultural workforce in Pakistan. These firms are typically operated by single entrepreneurs and most of them are family-run businesses and provide more than 30 percent share in GDP (Pakistan Federal Bureau of Statistics, 2005).

A review by Haque (2007) on Pakistan's development priorities of the last six decades illustrated that entrepreneurship had not been given due attention by the economic development planners. All this period, the government preferred largescale businesses and ignored the small and medium-sized enterprises. The historical evidence indicates that in the Pakistani context, industrialization means huge factories and plants operated by machinery and engaging a large number of workers. But in fact, it is the informal small-scale segment that can rule the industrial sector of Pakistan. Unfortunately, this has been constantly neglected in the national economic policies. Comparing entrepreneurial activity in different regions of Pakistan, Punjab province has the highest number of reputable business investors and keeps the highest early-stage business survival ratio and a lower business-closing ratio. However, the provinces of Baluchistan and Khyber Pakhtoon Khowa (KPK) have a large figure of individuals likely to launch the enterprise when comparing with other regions of Pakistan. Even so, Baluchistan has the highest early-stage entrepreneurial activity and new business manager ratio but has a very high business closing ratio. KPK is the province that has the lowest business closing ratio.

Women entrepreneurship is widely accepted all over the world due to women's capabilities to create employment opportunities, alleviate poverty and achieve sustainable economic development. In South Asia, the female workforce sharing proportion is among the lowest in the world. In this region, female entrepreneurship remains an extensively untapped source of job creation, fiscal development, and societal advancement. Despite considering small and mediumsized enterprises (SMEs) a key element for productions, fiscal growth, and GDP, yet only 8-9\% of official SMEs are possessed by females in the South Asian region when compared to 38-47\% in Eastern Europe, Central Asia and East Asia (Asian Development Bank, 2014). Among 56 economies surveyed on "Total Early-Stage Entrepreneurial Activity", both Pakistan and Bangladesh remain the lowest in rank in terms of female entrepreneurship participation. In Pakistan, only one-tenth of entrepreneurs are women (Kelley et al., 2011). The failure to utilize the potential of female counterparts costs the region severely. International Labor Organization (2016) revealed that South Asian women invest their money but invest more in the education, health, and comforts of their families and other relations than do males.

Among the South Asian states, Pakistan remains the lowest in terms of women's labor force participation ratio. According to Pakistan's Labor Force Survey, 2017-18, women's labor force participation ratio is only $20.1 \%$ when compared to $68 \%$ of their male counterparts (Mujahid et al., 2016). Being a developing country, Pakistan has a very small number of women participating in entrepreneurial activities compared with other developing countries of Asia. Only $1 \%$ of women are entrepreneurs compared to $21 \%$ of men (Kelley et al., 2012). About $12 \%$ of corporations retain female involvement as business owners in Pakistan when compared to more than $18 \%$ in South Asia and 34\% worldwide (World Bank, 2015). A report by World Bank showed that in Pakistan, the total percentage of female business owners was only $0.3 \%$ from 2001 to 2011. Women in Pakistan possess the lowest status in the world. They are often housebound under the traditional veil system. They are usually the biggest unpaid workforce in Pakistan (World Bank, 2007). The female population of Pakistan is comprised 51\% of the entire population (Nizami, 2010), but still, they are not qualified, trained, and empowered for entrepreneurship.

Gender disparities in entrepreneurship are also evident in Pakistan as Pakistan positioned 151 among 153 countries in 2020 rankings of gender parity index (World Economic Forum, 2020). Almost $60 \%$ of women are less likely to perceive business opportunities than men. A comparison $61 \%$ of men, only $34 \%$ of women find themselves proficient in launching a business (Kelley et al., 2012). According to UNESCO Institute for Statistics, women's participation in tertiary education is high in Pakistan. More than $45 \%$ of tertiary students are women, but still, they are less in number to 
participate in the business. Women are three times less likely to know an entrepreneur as compared to men (Kelley et al., 2012). This situation indicates a glaring disparity in women's social networks and as a result, women lack the capabilities to gain access to information and business networks. Pakistani women have to face disparate challenges when starting a business. They have to face legal boundaries which directly influence their capabilities to participate in the business. Moreover, married women are not allowed to be registered to a business as they are handicapped by inheritance laws that limit their access to their possessions. In this way, women lost their legacies and capabilities for launching their businesses (World Bank Group, 2015).

This situation highlighted the need to study the entrepreneurial attitude of female university students and to assess the effects of different factors strengthening or weakening these entrepreneurial attitudes of female students. The current study concentrates on exploring female students' attitudes towards entrepreneurship and assessing various factors that might contribute to strengthening or weakening these students' entrepreneurial attitudes. Thus, the study answers the following research questions:

1. To what extent, do the female university students demonstrate an entrepreneurial attitude?

2. What is the association between different factors and the entrepreneurial attitude of female university students?

3. To what extent, do the different factors predict the entrepreneurial attitude of female university students?

\section{METHODOLOGY}

The present study was descriptive and constituted a comprehensive scientific inquiry concentrating on the Punjab province of Pakistan. Eight public sector universities, i.e. Government College University Lahore (GCUL), Lahore College for Women University (LCWU), Punjab University (PU), University of Sargodha (UOS), University of Gujrat (UOG), Government College University Faisalabad (GCUF), The Islamia University of Bahawalpur (IUB), and Bahauddin Zakariya University (BZU) were selected for this research located in different regions of Punjab. The selected universities are general universities having faculties of Management Sciences, Social Sciences, and Natural Sciences.

In Pakistan, universities usually offer 'honor' and 'pass' degrees to the students. Honor degree consists of four-year undergraduate (Bachelor of Science; BS) programs, and pass degree consists of two years undergraduate programs leading to two years masters (MA/MSc) pass degrees. Pass master's degree is considered equal to BS-honor as both degrees comprise of 4-year of education. Thus, female students studying in their final year in honor degree and final year in pass degree were invited to take part in the study. Selection of final year students was their immediate shifting into practical lives after finishing their education, because students are supposed to be deciding about their prospective career in the final stage of their education. The students were selected through a multi-stage sampling technique from three different disciplines of sampled universities; Social Sciences, Management Sciences, and Natural Sciences. In multistage sampling, samples are taken at different stages from different clusters. In the present study, multi-stage sampling starts with the selection of province as Primary Sampling Units, of universities as Secondary Sampling Units inside the selected Province, of faculties as Tertiary Sampling Units inside the selected universities, and female students inside the selected faculties.

\section{Instrument}

\section{Entrepreneurial Attitude Scale}

A scale related to entrepreneurial attitude was adopted from Ali, Topping, and Tariq (2011) and further modified by the researchers to trace out the entrepreneurial attitude of female university students. The entrepreneurial attitude scale comprised of five subscales, i.e. self-efficacy (five items), need for achievement (three items), entrepreneurial intentions (two items), psychological comfort in entrepreneurship (four items), and risk-taking capacity (three items), and having a total of 17 items in it.

\section{Factor-based Scale}

A considerable review of the related literature assisted in constructing a close-ended scale to observe the impact of various factors in developing the entrepreneurial attitude of female university students. Shapero and Sokol's (1982) theoretical model provided a ground for tool development. The scale had the focus to discover female students' insights on the support of their family, society, technology, government initiatives, legal provisions crucial for women business start-up, local business environment, and tertiary education in developing their attitude towards entrepreneurship. The scale comprised of factor-based seven subscales having 35 items in it. These subscales were family support (six items), social support (seven items), legal provision (four items), the role of education (six items), technological support (four items), business environment (five items), and government initiatives (three items).

Both of the scales were combined to form a questionnaire and were developed on a Likert scale based on four options from strongly disagree to strongly agree. The neutral/undecided option did not add to the instrument. The reason was as given by Boone and Boone (2012) about Asian respondents that they usually possess a greater tendency to select undecided/neutral options when responding to an odd-point Likert scale. That is the reason researchers adopted a four- 
point Likert scale for their study. The researcher further accessed various field experts to ensure the content validity of the instruments. On their feedback, the students' questionnaire was revised. After that, the researchers piloted a study to assess the suitability of the questionnaire by drawing a random sample of 20 female students studying in the master's program at the Islamia University of Bahawalpur. The original version of the instrument had been given to students for highlighting difficult items. Afterward, the researchers finalized the research questionnaire considering respondents' feedback. Factors with their sample items of students' questionnaire were given in Table 1.

Table 1: Sample Items of Entrepreneurial Attitude and Factor-based Scales

\begin{tabular}{cll}
\hline \multicolumn{1}{l}{ Factors } & Items \\
\hline 1. & Self-efficacy & I believe that if I start my own business, I will certainly succeed. \\
\hline 2. & Desire to Achieve & If one solution of a problem does not work, I try to find another. \\
\hline 3. & $\begin{array}{l}\text { Intentions for } \\
\text { Personal Business }\end{array}$ & I would prefer to have my own successful business than to be in a well-paid job. \\
\hline 4. & $\begin{array}{l}\text { Psychological } \\
\text { Comfort } \\
\text { Entrepreneurship }\end{array}$ & I will be comfortable if I start my own business. \\
\hline 5. & $\begin{array}{l}\text { Risk-taking } \\
\text { Capacity }\end{array}$ & I can take decisions and stand firmly for them. \\
\hline 6. & Family Support & $\begin{array}{l}\text { I believe that my family members think that I should pursue a career as an } \\
\text { entrepreneur. }\end{array}$ \\
\hline 7. & Social Support & $\begin{array}{l}\text { I have good social networks that can be utilized when I decide to be an } \\
\text { entrepreneur. }\end{array}$ \\
\hline 8. & Legal provision & Lack of rules related to women prevents females from starting their business. \\
\hline 9. & Role of Education & $\begin{array}{l}\text { University education enhances my leadership skills that are essential for running a } \\
\text { self-business. }\end{array}$ \\
\hline 10. & $\begin{array}{l}\text { Technological } \\
\text { Support }\end{array}$ & $\begin{array}{l}\text { Internet marketing makes the entrepreneurship process easy for female } \\
\text { entrepreneurs. }\end{array}$ \\
\hline 11. & $\begin{array}{l}\text { Business } \\
\text { Environment }\end{array}$ & Our business environment provides many opportunities for female entrepreneurs. \\
\hline 12. & $\begin{array}{l}\text { Government } \\
\text { Initiatives }\end{array}$ & Government policies encourage females to start their businesses. \\
\hline
\end{tabular}

\section{Data Collection}

All ethical considerations were followed during the study. At first, official approval was obtained from registrars of all selected universities, and then heads of respective departments were contacted for data collection. The researchers obtained the enrollment record of female students studying in the final year of their respective programs from relevant departments. The researchers employed a multi-stage technique to draw samples of female students from eight selected universities. The departments which presented both an honor and master's programs; the researchers took the students studying only in honor programs. After completing all ethical considerations and official meetings, the researchers personally visited female students during their study hours and invited them to fill the questionnaires. In total, 2950 questionnaires were distributed, and 2704 female students filled the questionnaire that shows a high response rate (91.66\%). However, 128 questionnaires were found incomplete with missing items. Therefore, 2576 survey questionnaires were considered appropriate for statistical examination.

The total sample comprised of 2576 female students: 348 (13.5\%) from Punjab University Lahore, 392 (15.2\%) from Lahore College for Women University Lahore, 178 (6.9\%) from Government College University Lahore, 444 (17.2\%) from University of Gujrat, 259 (14.4\%) from University of Sargodha, 372 (10.1\%) from Government College University Faisalabad, 192 (7.5\%) from Bahauddin Zakariya University Multan, and 391 (15.2\%) from The Islamia University of Bahawalpur. Of the 2576 female students, 491 (19.1\%) were taking courses in Management Sciences, 1169 (45.4\%) in Social Sciences, and $916(35.6 \%)$ in Natural Sciences. The 2,272 (88.2\%) of the sampled students were between the age of 21-25 years. Out of the total sample, only $18.5 \%$ of the female students had businesswomen living in their own homes and $56.3 \%$ of the female students had businesswomen living in their neighbouring areas.

\section{Data Analysis}

The procedure of data examination initiated with the recording of data. Complete collected data were inserted into a datasheet of SPSS $16^{\text {th }}$ Version. For reducing data that assembled with two scales, exploratory factor analysis and then Principal Component Analysis (PCA) with varimax rotation were employed. The researchers applied the five-factor solution technique on the data assembled through the entrepreneurial attitude scale and the seven-factor solution technique on the data assembled through the factor-based scale. Five-factor and seven-factor extraction results presented appropriate outcomes on the obtained data. Cronbach's alpha was used to assess the internal consistency of each subscale of both the entrepreneurial attitude and the factor-based scales by following the recommendations of Cho and 
Kim (2015). Cronbach's alpha is the best choice among all published consistency coefficients, a value greater than 0.7 is considered consistent (Cho \& Kim, 2015). The obtained values of Cronbach alpha showed high internal reliability of all the subscales exhibited in Tables 2 and 3.

The collected data were analyzed through coding students' responses 1 for strongly disagree, 2 for disagree, 3 for agree, and 4 for 'strongly agree'. Then researchers reversed the coding of 10 items whose meanings were opposite to that of the subscale to which they had initially been allocated. The female students were allocated scores on each subscale equal to the mean of their responses to its constituent items. After statistical examination of collected data, results were presented in tabular format. To enhance the overall assessment quality of the instrument and summarization of results, the researchers put together strongly agree with agreeing and same with negative choices. Categories were joined together to increase the entire measurement quality of an instrument (Linacre \& Wright, 2006).

\section{RESULTS/FINDINGS}

Regarding university-wise variability of female students' entrepreneurial attitudes, the result of $\operatorname{ANOVA~F}(7,2568)=$ $5.58, \mathrm{p}<0.001$ showed statistically highly significant differences among university female students' entrepreneurial attitudes. The mean values varied between 2.85 and 3.00 for all eight universities.

Regarding faculty-wise variation among female university students' entrepreneurial attitudes, the result of ANOVA F(2, $2573)=13.38, \mathrm{p}<0.001$ revealed statistically highly significant differences among female university students' entrepreneurial attitudes. Mean values of three faculties were Management Sciences $(M=3.01)$, Social Sciences $(M=$ 2.94) and Natural Sciences $(M=2.90)$. These values varied between 2.90 and 3.01 for all three faculties.

Table 2 presented the mean scores representing self-reported students' entrepreneurial attitude. The female university students demonstrated strong agreement on the indicators of entrepreneurial attitude including self-efficacy, need for achievement, entrepreneurial intentions, psychological comfort in entrepreneurship, and risk-taking capacity. Overall mean score $(M=2.94)$ showed a strong self-reported entrepreneurial attitude among the female participants (Table 2).

Table 2: Descriptive Statistics for Subscales of Overall Entrepreneurial Attitude

\begin{tabular}{|c|c|c|c|c|}
\hline Subscale & Number of Items & Mean & Standard Deviation & Cronbach's Alpha \\
\hline Self-Efficacy & 5 & 3.06 & 0.441 & 0.870 \\
\hline Need for Achievement & 3 & 3.10 & 0.499 & 0.752 \\
\hline Entrepreneurial Intentions & 2 & 2.35 & 0.767 & 0.707 \\
\hline Psychological Comfort in Entrepreneurship & 4 & 2.86 & 0.594 & 0.796 \\
\hline Risk-taking Capacity & 3 & 3.13 & 0.493 & 0.715 \\
\hline Total & 17 & 2.94 & 0.387 & \\
\hline
\end{tabular}

*Subscale scores differ from a minimum of 1 to a maximum of 4

Table 3 provided the mean scores representing female students' responses on the effect of different factors on their entrepreneurial attitude. Mean scores revealed that the female university students consider technology big support for them if they choose entrepreneurship as a career $(\mathrm{M}=3.24)$. Mean scores representing the participants' responses about the business environment $(M=2.35)$ and social support $(M=2.38)$ showed that female students had deteriorated satisfaction with these factors. Data also revealed that legal provisions for women to launch their businesses were least supportive for the female university students ( $\mathrm{M}=1.97)$ (Table 3 ).

Table 3: Descriptive Statistics for Subscales of different Factors affecting Entrepreneurial Attitude of Female University Students

\begin{tabular}{cccccc}
\hline Sr. \# & Scales & Number of Items & Mean & Standard Deviation & Cronbach's Alpha \\
\hline 1. & Family Support & 6 & 2.61 & 0.562 & 0.802 \\
\hline 2. & Social Support & 7 & 2.38 & 0.394 & 0.744 \\
\hline 3. & Legal provision & 4 & 1.97 & 0.521 & 0.725 \\
\hline 4. & Role of Education & 6 & 2.93 & 0.482 & 0.747 \\
\hline 5. & Technological Support & 4 & 3.24 & 0.452 & 0.703 \\
\hline 6. & Business Environment & 5 & 2.35 & 0.525 & 0.733 \\
\hline 7. & Government Initiatives & 3 & 2.55 & 0.619 & 0.704 \\
\hline
\end{tabular}

*Subscale scores differ from a minimum of 1 to a maximum of 4

Findings demonstrated that all the factors mentioned in Table 4 have a significantly direct association with all the indicators of students' entrepreneurial attitude except the legal provision. Legal provision has a significant negative association with all the indicators of entrepreneurial attitude. The role of education showed the highest scores of Pearson 
correlation coefficients for all the indicators of entrepreneurial attitude. Technological support demonstrates high values for all indicators of entrepreneurial attitude. However, legal provision demonstrated comparatively negative values of Pearson correlation coefficients for all indicators of entrepreneurial attitude (Table 4).

Table 4: Values of Pearson Correlation Coefficients showing relationships between different Factors and Indicators of Overall Entrepreneurial Attitude of Female University Students

\begin{tabular}{|c|c|c|c|c|c|c|}
\hline & $\begin{array}{c}\text { Self- } \\
\text { Efficacy }\end{array}$ & $\begin{array}{c}\text { Need for } \\
\text { Achievement }\end{array}$ & $\begin{array}{l}\text { Entrepreneurial } \\
\text { Intentions }\end{array}$ & $\begin{array}{l}\text { Psychological } \\
\text { Comfort }\end{array}$ & $\begin{array}{c}\text { Risk- } \\
\text { taking } \\
\text { capacity }\end{array}$ & $\begin{array}{c}\text { Overall } \\
\text { Entrepreneurial } \\
\text { Attitude }\end{array}$ \\
\hline Family Support & $0.241 *$ & $0.166^{*}$ & $0.309 *$ & $0.360 *$ & $0.171 *$ & $0.370^{*}$ \\
\hline Social Support & $0.168^{*}$ & $0.078^{*}$ & $0.229 *$ & $0.300^{*}$ & $0.100 *$ & $0.270^{*}$ \\
\hline $\begin{array}{l}\text { Legal } \\
\text { provision }\end{array}$ & $-0.143^{*}$ & $-0.156^{*}$ & $-0.052 *$ & $-0.106^{*}$ & $-0.175^{*}$ & $-0.173 *$ \\
\hline $\begin{array}{ll}\text { Role } & \text { of } \\
\text { Education } & \\
\end{array}$ & $0.447 *$ & $0.393 *$ & $0.426^{*}$ & $0.663^{*}$ & $0.334 *$ & $0.674^{*}$ \\
\hline $\begin{array}{l}\text { Technological } \\
\text { Support }\end{array}$ & $0.316^{*}$ & $0.371 *$ & $0.172 *$ & $0.380 *$ & $0.314 *$ & $0.447^{*}$ \\
\hline $\begin{array}{l}\text { Business } \\
\text { Environment }\end{array}$ & $0.211 *$ & $0.162 *$ & $0.259 *$ & $0.297 *$ & $0.153^{*}$ & $0.318^{*}$ \\
\hline $\begin{array}{l}\text { Government } \\
\text { Initiatives }\end{array}$ & $0.134 *$ & $0.139 *$ & $0.153^{*}$ & $0.201 *$ & $0.107 *$ & $0.214 *$ \\
\hline
\end{tabular}

*value is significant at the level of .001.

Multiple regression was run on the data and found that the reported factors explain $51.7 \%$ of the variance in the female university students' overall entrepreneurial attitude $\left(\mathrm{R}^{2}=0.517\right)$. The values of squared semi-partial correlation coefficients showed the unique contribution of predictor variables in explaining variances in the respondents' overall entrepreneurial attitude. Results showed that the role of education exclusively explained $16.3 \%$ of the variance in the female students' entrepreneurial attitude. The other predictor variables such as family support, technological support, and legal provision though contribute to explaining variances in female students' overall entrepreneurial attitude, yet their exclusive share is comparatively low. Similarly, the factors like business environment, social support, and government initiatives though contribute to explaining the variances in female students' entrepreneurial attitude yet their share was negligible. Values of standardized beta showed that a one-unit increase in the role of education causes a 0.505 unit increase in the female students' entrepreneurial attitude. The standardized beta values for family support, technological support, and business environment revealed that one unit increase in these variables separately causes $0.131,0.130$, and 0.103 unit increase in the female students' entrepreneurial attitude respectively. However, the standardized beta values for government initiatives and legal provision indicated if the current scenario of government initiatives and legal provision extends one unit, it will cause a -0.036 and -0.125 unit decrease in the female students' entrepreneurial attitude. The results demonstrated that two factors, i.e. government initiatives and legal provision were not supportive for developing entrepreneurial attitude among female students. Kinnear and Gray proposed to compare the values of $\mathrm{R}^{2}$ with Cohen's eta squared to estimate effect size (Kinnear \& Gray, 2011). According to Cohen's classification of effect size, the effect size of the predictor variables was large on the criterion variable (Cohen, 1992; Table 5).

Table 5: Results of Multiple Regression Analysis run with different Factors as Predictor Variables and overall Entrepreneurial Attitude as Criterion Variable

\begin{tabular}{lllc}
\hline Predictors & $\beta($ Standard) & $\mathrm{t}$-value & $\mathrm{sp}^{2}$ \\
\hline Role of Education & 0.505 & $29.437 * * *$ & 0.163 \\
\hline Family Support & 0.131 & $8.653 * * *$ & 0.014 \\
\hline Technological Support & 0.130 & $8.103 * * *$ & 0.012 \\
\hline Business Environment & 0.103 & $6.177 * * *$ & 0.007 \\
\hline Legal provision & -0.125 & $8.211 * * *$ & 0.013 \\
\hline Social Support & 0.086 & $5.279 * * *$ & 0.005 \\
\hline Government Initiatives & -0.036 & $2.262 * *$ & 0.001 \\
\hline $\mathrm{R}^{2}=0.517, \mathrm{~F}(7,2568)=392.622 * * *$ & & \\
\hline
\end{tabular}

Criterion Variable: Overall Entrepreneurial Attitude; $* \mathrm{p}<.05, * * \mathrm{p}<.01, * * * \mathrm{p}<.001$ (two-tailed tests)

\section{DISCUSSION}

The current study explored the overall entrepreneurial attitude of female university students enrolled in Pakistani universities. The findings demonstrated that female students possessed a positive attitude towards adopting entrepreneurship as a career. When comparing sub-factors of overall entrepreneurial attitude, female students possessed 
the highest risk-taking capacity over self-efficacy, entrepreneurial intentions, need for achievement, and psychological comfort in entrepreneurship and possessed the lowest entrepreneurial intentions. The female students exhibited an overall positive entrepreneurial attitude. The results of the present study supported the findings of Lee et al. (2005) who asserted that every entrepreneur requires a positive entrepreneurial attitude when she starts an endeavor. When the real challenge comes to entrepreneurs in the form of impediments and obstacles, some entrepreneurs in this situation eventually lose their passion and energy due to the fear that they might make mistakes in facing the challenges and thus incapable to recuperate again. This is the actual stage where the entrepreneur's positive attitude and self-confidence work and she pledges to continue her entrepreneurial endeavour regardless of having obstacles and constraints in her ways. The results of the present study also supported the results of Prodan and Drnovsek (2010) who explained that an individual's attitude explains more than 50 percent of the variations in the individual's intentions. Similarly, Hsu et al. (2019) revealed that individuals who are excited and willing to launch a business can have a different outlook than those who are unwilling to start a fresh endeavor. Esfandiar et al. (2019) also found that an entrepreneurial attitude is an individual's inclination to launch and run a business. If individuals do not attract to start an entrepreneurial endeavour, all business-related tasks and processes will become difficult than those truly interested in business. Determining the factors contributing to developing entrepreneurial attitude supports educational practitioners to take steps in strengthening female students' spirit to psychologically face these challenges. It is an encouraging sign that Pakistani female university students have a positive attitude towards entrepreneurship.

The study showed the association between entrepreneurial attitude and different factors. Results showed that all the factors were positively associated with the indicators of entrepreneurial attitude except the indicator of 'legal provision' which has a negative association with the affecting factors. The factor role of education was strongly associated with all the indicators of entrepreneurial attitude. Its exclusive contribution in explaining the variance in entrepreneurial attitude is the highest among all the reported factors. The results of this inquiry were consistent with the findings of Turker and Selcuk (2009) who revealed if higher education institutions ensure certain knowledge and stimulation with a particular focus on business, the propensity of young students to pursue entrepreneurship might be high. Liu et al. (2019) also highlighted that entrepreneurship education has a substantial and encouraging impact on the entrepreneurial attitude of college students. Similarly, family support emerged as a second major factor that contributes to strengthening female students' overall entrepreneurial attitude. The present study revealed that family's willingness and moral and financial support strengthen the capabilities of Pakistani young women to accept entrepreneurship as a career. Previous studies also identified that family as a positive influencing factor develops entrepreneurial attitude among the students (Kirkwood, 2007). Similarly, the findings of Ali, Topping, Tariq, et al. (2011) highlighted the importance of parents' support in students' entrepreneurial experiences. The findings of the present study also supported the results of Denanyoh et al. (2015) who found that emotional support of family is a significant contributor to the development of entrepreneurial attitude and intentions among the students in Ghana. Laguía et al. (2019) also identified that perceived family support is positively linked with entrepreneurial attitude in the students. In the Pakistani context, family support becomes crucial for female students if they want to adopt entrepreneurship as a career. The third contributor to entrepreneurial attitude is technological support. The study demonstrated that technological support in venture creation is very helpful for many women who are inclined to start their own businesses. It shows that Pakistani female university students are well aware of the influential role of technology in entrepreneurship and keen to utilize it in their careers as entrepreneurs. As a facilitator, technological tools make entrepreneurial tasks easy for women. The findings of the present study sustained the results of Bailetti (2012) who concluded that technology is a big innovation in the entrepreneurial fields. It has opened prospects for entrepreneurs and women can easily access venture creation and further flourishing these ventures. Thus, technology may be proved a blessing and stronger support for women for starting their own business and consequently can refine the female students' entrepreneurial attitudes. These findings also supported the results of Poudel et al. (2019) who found that technological proficiency is essential for an entrepreneurial business to grow and economically flourish. Similarly, business environment and social support also contributed to developing female students' entrepreneurial attitude but their contribution is significantly low. This indicated that the business environment and social support are comparatively less supportive for female students to start entrepreneurship in Pakistan. This supports the findings of Misoska et al. (2016) who revealed that promoting a favorable entrepreneurial environment will encourage a more positive attitude and feeling of being more confident that ultimately lead to greater entrepreneurial intentions. These findings were also consistent with the results of Aldrich (1990) who suggested if the business atmosphere is favorable in emerging economies; fresh venture creation can prosper and stands for an extended period. The university students consider venture creation an appropriate and desired occupation but their outlooks are not positive towards starting entrepreneurial endeavor in the market. Resultantly, students' inclination towards adopting entrepreneurship remains low (Veciana et al., 2005). The findings of this research supported the results of Unni and Rani (2003) who revealed that social norms hinder women's economic activities. Thomas et al. (2014) also identified that social values and norms may directly influence entrepreneurial attitude. However, Autio et al. (2001) found that social norms are the weakest component influencing the entrepreneurial attitude. Similarly, Trivedi (2016) discovered that social support does not have significant and positive effects on entrepreneurial intentions. The present study highlighted that students' ratings of government initiatives were positively associated with students' entrepreneurial attitude but negatively linked when the effects of other factors had been taken into account (i.e. statistically controlled through the use of multiple regression analysis). Thus, its sole contribution in explaining variance 
in overall entrepreneurial attitude was negative. The findings of the present study sustained the results of Ali et al. (2010) who explored that government is a determinant for students' entrepreneurial attitude. These are the students who observe the impact of different policies and initiatives of government on their routine lives. The self-business might be influenced by administrative policies and implementation strategies of the government. The government may promote entrepreneurial actions through decreasing tariffs as well as initiating business-friendly steps such as female quota, tariff subsidy, and establishment of regional offices for entrepreneurial consultancy services. Regarding legal provision, students' ratings of the legal provision were negatively related to overall entrepreneurial attitude both in correlation coefficients and when the effects of other factors had been taken into account (i.e. statistically controlled through the use of multiple regression analysis). Previous studies also highlighted that women workers were being exploited by not giving them legal rights equal to those of men. The findings of Yasin et al. (2010) claiming that in Pakistan, women have to face numerous challenges that are connected to religion, socio-culture, discrimination, provocation, and the absence of equal opportunities. These obstacles restrict Pakistani women to participate in different occupations.

\section{CONCLUSION}

The major thrust of the present study is to explore female students' entrepreneurial attitudes and examine different factors contributing to predict these students' entrepreneurial attitudes. The survey research infers that the presence of overall entrepreneurial attitude is high among female university students in Pakistan. However, female students of Management Sciences have the highest entrepreneurial attitude over the female students of Social Sciences and Natural Sciences. Similarly, female students of Social Sciences have a higher entrepreneurial attitude than female students of Natural Sciences.

Exploring relationships between different factors and female university students' entrepreneurial attitude, the study concludes that all the explored factors such as the role of education, family support, technological support, business environment, social support, and government initiatives have statistically significant and positive relationships with female students' overall entrepreneurial attitude. But the only legal provision has a negative relationship with female students' entrepreneurial attitude. This indicates that female students viewed that women in Pakistan might not be given legal rights to start their entrepreneurship.

The shared contribution of predicting factors in explaining variance in the overall entrepreneurial attitude of the female students is statistically highly significant. However, these predicting factors contribute separately in different ways in explaining variations in students' entrepreneurial attitude. The first key factor is the role of education which has the highest impact on female students' entrepreneurial attitude in the Pakistani context. The findings of the present study support the major role being played by university education in the growth of female students' entrepreneurial attitude. Family support and technological assistance appear as contributors to the entrepreneurial attitude of the female students. Business environment and social support contribute but their share remains very low in enhancing students' entrepreneurial attitude. In a country like Pakistan, female students perceive legal provision and government initiatives as secondary factors. These factors might not be supportive in strengthening female students' attitudes towards adopting entrepreneurship. In their opinion, education, parents' support, and technology are more supportive for them if they want to adopt entrepreneurship as a career.

\section{LIMITATIONS AND FUTURE RESEARCH}

The study was implemented only in the Punjab province of Pakistan. Thus, the generalization of the outcomes is limited to Punjab province. It is, therefore, suggested that further inquiry needs to be done in other provinces of Pakistan to get a broad picture of the scenario. The sample selected only from the female students may not represent the holistic views of the male students regarding entrepreneurial attitude and different affecting factors; thus, further research is needed to empirically investigate the male students' views about entrepreneurial attitude and different affecting factors.

The outcomes of the present research revealed that among all the influencing factors, the role of university education has the highest effects on students' entrepreneurial attitude. This important indicator primarily requires a supportive academic environment for nurturing entrepreneurial attitudes among female students. The study outcomes predict if higher education institutions provide proper knowledge and inspiration for entrepreneurship to female students, the chances of adopting an entrepreneurship career may be high among these students and they might be expressed their strong inclination towards entrepreneurship. Therefore, the study recommends the inclusion of entrepreneurship courses into undergraduate and postgraduate programs in Pakistani universities. These courses will not only impart theoretical knowledge of how to design and launch business, but also cultivate innovative, decision-making, risk-taking, and management skills among female students through adequate problem-solving and project development approaches and techniques.

Policy-makers should invest in higher education with deliberate concern for venture creation. This will certainly enhance the capacity-building of female students towards entrepreneurship. Universities should collaborate with manufacturing and production sectors and should organize internship programs for female students. Universities should also arrange entrepreneurial career development programs for female students to display their talents in a competitive environment. The Pakistani government may provide scholarships for proven entrepreneurial talents. The government should also provide partnership and interaction between higher education institutions and production sectors with a special emphasis 
on capacity-building for entrepreneurship. The family and society also emerged as chief contributors in stimulating and inspiring female students towards involving in entrepreneurial endeavors. Awareness about venture creation may be provided to parents, close relatives, and society members through media and convince them to make their women contribute to national entrepreneurship activities. The family may need to be incorporated in entrepreneurship attitude models and theories as the family ascertained a significant element affecting students' choice to become entrepreneurs.

\section{ACKNOWLEDGMENT}

The authors have received no funding from any supporting or funding agency.

\section{AUTHORS' CONTRIBUTION}

Shahnaz Perveen is the primary author of this research paper. This research paper is a part of her doctoral thesis.

Muhammad Ayub Buzdar contributed to the data analysis and interpretation section.

Akhtar Ali contributed to results, conclusion, and proofreading.

\section{REFERENCES}

1. Aldrich, H. E. (1990). Using an Ecological Perspective to Study Organizational Founding Rates. Entrepreneurship Theory and Practice, 14(3), 7-24. https://doi.org/10.1177/104225879001400303

2. Ali, A., Topping, K. J., \& Tariq, R. H. (2011). Entrepreneurial Attitudes among Potential Entrepreneurs. Pakistan Journal of Commerce and Social Sciences, 5(1), 12-46. http://www.jespk.net/publications/43.pdf

3. Ali, A., Topping, K., Tariq, R. H., \& Wakefield, P. (2011). Entrepreneurial Propensity in Pakistan and UK: A comparative study of Pakistani and UK Prospective Teachers. Pakistan Journal of Commerce and Social Sciences, 5(2), 243-265. http://www.jespk.net/publications/60.pdf

4. Ali, I., Tajddini, K., Rehman, K. ur, Ali, awaria F., \& Ahmed, I. (2010). University Student's inclination of Governance, and its Effects on Entrepreneurial Intentions: An Empirical Analysis. International Journal of Trade, Economics and Finance, 1(1), 36-39. https://doi.org/10.7763/IJTEF.2010.V1.7

5. Asian Development Bank. (2014). Asian Development Bank Annual Report 2013 (pp. 1-53). Asian Development Bank. https://www.adb.org/sites/default/files/institutional-document/42741/adb-annual-report2013.pdf

6. Autio, E., H. Keeley, R., Klofsten, M., G. C. Parker, G., \& Hay, M. (2001). Entrepreneurial Intent among Students in Scandinavia and in the USA. Enterprise and Innovation Management Studies, 2(2), 145-160. https://doi.org/10.1080/14632440110094632

7. Bailetti, T. (2012). Technology Entrepreneurship: Overview, Definition, and Distinctive Aspects. Technology Innovation Management Review, 2(2), 5-12. https://doi.org/10.22215/timreview/520

8. Boone, H. N., \& Boone, D. A. (2012). Analyzing Likert Data. The Journal of Extension, 50(2), 1-5. https://archives.joe.org/joe/2012april/pdf/JOE_v50_2tt2.pdf

9. Bosma, N., Hill, S., Ionescu-Somers, A., Kelley, D., Levie, J., \& Tarnawa, A. (2020). GEM Global Report 2019/2020 (pp. 1-232). Global Entrepreneurship Research Association, London Business School. https://www.babson.edu/media/babson/assets/global-entrepreneurship-monitor/2019-2020-GEM-GlobalReport.pdf

10. Cho, E., \& Kim, S. (2015). Cronbach's Coefficient Alpha: Well Known but Poorly Understood. Organizational Research Methods, 18(2), 207-230. https://doi.org/10.1177/1094428114555994

11. Cohen, J. (1992). Statistical Power Analysis. Current Directions in Psychological Science, 1(3), 98-101. https://doi.org/10.1111/1467-8721.ep10768783

12. Denanyoh, R., Adjei, K., \& Nyemekye, G. E. (2015). Factors That Impact on Entrepreneurial Intention of Tertiary Students in Ghana. International Journal of Business and Social Research, 5(3), 19-29. https://doi.org/10.15678/EBER.2015.030103

13. Esfandiar, K., Sharifi-Tehrani, M., Pratt, S., \& Altinay, L. (2019). Understanding entrepreneurial intentions: A developed integrated structural model approach. Journal of Business Research, 94, 172-182. https://doi.org/10.1016/j.jbusres.2017.10.045

14. Gürol, Y., \& Atsan, N. (2006). Entrepreneurial characteristics amongst university students: Some insights for entrepreneurship education and training in Turkey. Education + Training, 48(1), 25-38. https://doi.org/10.1108/00400910610645716

15. Haque, N. U. (2007). Entrepreneurship in Pakistan (pp. 1-61). Pakistan Institute of Development Economics, Islamabad. https://www.pide.org.pk/pdf/Working\%20Paper/WorkingPaper-29.pdf

16. Hsu, D. K., Burmeister-Lamp, K., Simmons, S. A., Foo, M.-D., Hong, M. C., \& Pipes, J. D. (2019). "I know I can, but I don't fit": Perceived fit, self-efficacy, and entrepreneurial intention. Journal of Business Venturing, 34(2), 311-326. https://doi.org/10.1016/j.jbusvent.2018.08.004

17. International Labor Organization. (2016). Women at work: Trends 2016. International Labor Organization Geneva. https://www.ilo.org/wcmsp5/groups/public/---dgreports/---dcomm/--publ/documents/publication/w cms_457317.pdf 
18. Kelley, D. J., Brush, C. G., Greene, P. G., Litovsky, Y., \& Global Entrepreneurship Research Association. (2012). Global Entrepreneurship monitor 2012 Women's Report. Babson College. https://www.babson.edu/me dia/babson/site-assets/content-assets/about/academics/centres-and-institutes/blank-institute/global-research/glo bal-entrepreneurship-monitor/reports/GEM-2012-Womens-Report.pdf

19. Kelley, D. J., Singer, S., \& Herrington, M. (2011). The Global Entrepreneurship Monitor 2011 Global Report (pp. 1-38) [Global Reports]. Babson College. https://www.gemconsortium.org/report/gem-2011-global-report

20. Kinnear, P. R., \& Gray, C. D. (2011). IBM SPSS statistics 18 made simple. Psychology Press.

21. Kirkwood, J. (2007). Igniting the Entrepreneurial Spirit: Is the Role Parents Play Gendered? International Journal of Entrepreneurial Behaviour \& Research, 13, 39-59. https://doi.org/10.1108/13552550710725174

22. Klapper, L., \& Delgado, J. (2007). World Bank Group Entrepreneurship Survey: Data Overview. SSRN Electronic Journal. https://doi.org/10.2139/ssrn.1022664

23. Laguía, A., Moriano, J. A., \& Gorgievski, M. J. (2019). A psychosocial study of self-perceived creativity and entrepreneurial intentions in a sample of university students. Thinking Skills and Creativity, 31, 44-57. https://doi.org/10.1016/j.tsc.2018.11.004

24. Lee, S. M., Chang, D., \& Lim, S. (2005). Impact of Entrepreneurship Education: A Comparative Study of the U.S. and Korea. The International Entrepreneurship and Management Journal, 1(1), $27-43$. https://doi.org/10.1007/s11365-005-6674-2

25. Linacre, J. M., \& Wright, B. D. (2006). A user's guide to BIGSTEPS: Rasch-model computer program (3rd ed.). Mesa Press. http://citeseerx.ist.psu.edu/viewdoc/download?doi=10.1.1.639.4296\&rep=rep1\&type=pdf

26. Liu, X., Lin, C., Zhao, G., \& Zhao, D. (2019). Research on the Effects of Entrepreneurial Education and Entrepreneurial Self-Efficacy on College Students' Entrepreneurial Intention. Frontiers in Psychology, 10(869), 1-9. https://doi.org/10.3389/fpsyg.2019.00869

27. Maresch, D., Harms, R., Kailer, N., \& Wimmer-Wurm, B. (2016). The impact of entrepreneurship education on the entrepreneurial intention of students in science and engineering versus business studies university programs. Technological Forecasting and Social Change, 104, 172-179. https://doi.org/10.1016/j.techfore.2015.11.006

28. Mian, S. A., \& Qureshi, M. S. (2011). Global Entrepreneurship Monitor Pakistan Report 2011 (pp. 1-62). Institute of Business Administration Karachi. https://ced.iba.edu.pk/GEM_AR_2011.pdf

29. Misoska, A. T., Dimitrova, M., \& Mrsik, J. (2016). Drivers of entrepreneurial intentions among business students in Macedonia. Economic Research-Ekonomska Istraživanja, 29(1), 1062-1074. https://doi.org/10.1080/1331677X.2016.1211956

30. Mujahid, N., Shabbir, M. S., \& Shahbaz, M. (2016). Labour Market Conditions-Female Labour Supply Nexus: The Role of Globalization in Pakistan. Global Business Review, 17(1), 68-87. https://doi.org/10.1177/0972150915610686

31. Ndofirepi, T. M. (2020). Relationship between entrepreneurship education and entrepreneurial goal intentions: Psychological traits as mediators. Journal of Innovation and Entrepreneurship, 9(2), 1-20. https://doi.org/10.1186/s13731-020-0115-x

32. Nizami, N. S. (2010). Pakistan Economic Survey 2009-10: Population, Labour Force and Employment. Finance Division, Ministry of Finance, Government of Pakistan. http://www.finance.gov.pk/survey/cha pter_10/16_Population.pdf

33. Pakistan Federal Bureau of Statistics. (2005). Economic Census of Pakistan: National report. The Bureau. https://catalogue.nla.gov.au/Record/4851390

34. Potter, J., \& Marchese, M. (2008). A Review of Local Economic and Employment Development Policy Approaches in OECD Countries: Part III Case Studies of Regional Economic Development Approaches (pp. 1201) [OECD Local Economic and Employment Development (LEED) Papers]. OECD Publishing. https://www.oecd.org/employment/leed/42771716.pdf

35. Poudel, K. P., Carter, R., \& Lonial, S. (2019). The Impact of Entrepreneurial Orientation, Technological Capability, and Consumer Attitude on Firm Performance: A Multi-Theory Perspective. Journal of Small Business Management, 57(52), 268-295. https://doi.org/10.1111/jsbm.12471

36. Prodan, I., \& Drnovsek, M. (2010). Conceptualizing academic-entrepreneurial intentions: An empirical test. Technovation, 30(5-6), 332-347. https://doi.org/10.1016/j.technovation.2010.02.002

37. Shabbir, M. S., Shariff, M. N. M., Alshaibani, Y. H., Faisal, M., \& Salman, R. (2018). Entrepreneurship and skills development for socioeconomic growth; present landscape and future agenda for Pakistan. Academy of Entrepreneurship Journal, 24(3), 1-12. https://www.abacademies.org/articles/entrepreneurship-and-skillsdevelopment-for-socioeconomic-growth-present-landscape-and-future-agenda-for-pakistan-7405.html

38. Shapero, A., \& Sokol, L. (1982). The social dimensions of entrepreneurship. Encyclopedia of Entrepreneurship, 72-90. https://www.econbiz.de/Record/the-social-dimensions-of-entrepreneurship-shapero-albert/10002821584

39. Asian Productivity Organization. (2003). Entrepreneurship and innovation in the knowledge-based economy: Challenges and strategies. Asian Productivity Organization. https://www.apo-tokyo.org/publications/wpcontent/uploads/sites/5/ind-06-ei.pdf

40. Thomas, A., Passaro, R., \& Scandurra, G. (2014). The Perception of the Contextual Factors as Predictor of Entrepreneurial Intent: Evidences from an Empirical Survey. Journal of Enterprising Culture, 22(04), 375-400. https://doi.org/10.1142/S0218495814500162 
41. Tripathi, A. (2019). SMEs in Saudi Arabia-an innovative tool for country's economic growth. Science International, 31(2), 261-267. http://www.sci-int.com/pdf/636897196571439497.edited-2.pdf

42. Trivedi, R. (2016). Does university play significant role in shaping entrepreneurial intention? A cross-country comparative analysis. Journal of Small Business and Enterprise Development, 23(3), 790-811. https://doi.org/10.1108/JSBED-10-2015-0149

43. Turker, D., \& Sonmez Selcuk, S. (2009). Which factors affect the entrepreneurial intention of university students? Journal of European Industrial Training, 33(2), 142-159. https://doi.org/10.1108/03090590910939049

44. Unni, J., \& Rani, U. (2003). Social Protection for Informal Workers in India: Insecurities, Instruments and Institutional Mechanisms. Development and Change, 34(1), 127-161. https://doi.org/10.1111/1467-7660.00299

45. Veciana, J. M., Aponte, M., \& Urbano, D. (2005). University Students' Attitudes Towards Entrepreneurship: A Two Countries Comparison. The International Entrepreneurship and Management Journal, 1(2), 165-182. https://doi.org/10.1007/s11365-005-1127-5

46. World Bank. (2007). GEM Country Brief Pakistan 2007. International Finance Corporation; Gender Entrepreneurship Markets.

47. World Bank. (2015). Pakistan-Enterprise Survey 2013 (pp. 1-129). The World Bank. https://microdata.worldbank.org/index.php/catalog/2363

48. World Bank Group. (2015). Women, Business and the Law 2016: Getting to Equal. The World Bank. https://doi.org/10.1596/978-1-4648-0677-3

49. World Economic Forum. (2020). Global Gender Gap Report 2020. World Economic Forum.

50. Xavier, S. R., Kelley, D. J., Kew, J., Herrington, M., \& Vorderwülbecke, A. (2012). Global Entrepreneurship Monitor (pp. 1-87) [Global Reports]. https://www.gemconsortium.org/report/gem-2012-global-report

51. Yasin, G., Fani, M. I., \& Yaseen, A. (2010). Determinants of gender-based wage discrimination in Pakistan: A confirmatory factor analysis approach. International Research Journal of Finance and Economics, 55, 177196. 